\title{
OXIDATION OF ETHYL ACETATE ON Fe-Mn OXIDES FROM NITRATES DEPOSITED BY IMPREGNATION ON MONOLITHS OF AISI 304 STAINLESS STEEL
}

\author{
FLAVIA G. DURÁN*, BIBIANA P. BARBERO, LUIS E. CADÚS \\ Instituto de Investigaciones en Tecnología Química (INTEQUI), Universidad Nacional de San Luis - CONICET, \\ Chacabuco y Pedernera, 5700, San Luis, Argentina.
}

\begin{abstract}
The iron-manganese mixed monolithic catalysts were obtained by impregnation from nitrates as precursors. A monolithic support was studied with and without alumina as surface generator. The characterization consisted in XRD, SEM, Adherence test, $\mathrm{S}_{\mathrm{BET}}$ and TPR. The monolith was evaluated in the combustion of ethyl acetate. The preparation method was very satisfactory in terms of reproducibility and adherence of the deposited phase. The higher activity of IFeMnx with respect to Al3FeMnx may be attributed for the formation of the solid solution where the Fe is introduced to the bixbyite structure. However, the presence of defective MnOx species in monoliths without alumina which might help to improve their performance is observed.
\end{abstract}

Keywords: Monoliths, AISI 304, Oxidation, Ethyl Acetate.

\section{INTRODUCTION}

Volatile organic compounds (VOCs) not only contribute to a large extent to atmospheric air pollution due to its toxicity, but they are also the main precursors of tropospheric ozone and $\operatorname{smog}{ }^{1-6}$.

Within the processes of compound removal, the catalytic oxidation is considered a potential method of control of VOCs emissions due to its low NOx emissions, as well as low cost and high destructive efficiency ${ }^{7-9}$. The most used catalysts for the reduction of VOCs emissions are divided in two categories: i) those based on noble metals; and ii) those based on transition metal oxides. The catalysts of noble metals of Pt and Pd are, in general, more active than those of transition metals ${ }^{10-13}$. However, their high cost, limited availability and sensitivity to high temperatures turn the choice to the second group, with metals such as $\mathrm{Cr}, \mathrm{Mn}, \mathrm{Co}, \mathrm{Ni}, \mathrm{Fe}, \mathrm{Cu}$ and $\mathrm{V}^{14-16}$; in particular, the manganese oxides are, among the transition-metal compounds, the materials most efficient and friendly to the environment. Their main features are: i) the presence of multiple states of oxidation so that throughout the reaction, the metal is reduced by the hydrocarbon and then, re-oxidized by the oxygen constituting, thus, a redox cycle; ii) thermal stability; iii) good resistance to poisoning by halide; and iv) low volatility ${ }^{17-21}$. The ideal manganese catalyst would be a manganese oxide with oxidation state +4 , which is possible ${ }^{22}$ with cryptomelane structures ${ }^{23}$ or perovskite structures ${ }^{24}$. $\mathrm{MnO}_{2}$ is unstable at high temperatures, which are feasible due to the exothermic character of the reaction, generating possible hot points. Non-crystalline manganese oxide is a defective material with an excellent catalytic performance ${ }^{25}$. The presence of other cations as copper or iron could favour the existence of those manganese species ${ }^{26}$. Durán et al ${ }^{20,}{ }^{27}$ have established $\mathrm{Mn} / \mathrm{Fe}$ atomic ratio equal to 3.0 as the optimal for the $\mathrm{Mn}-\mathrm{Fe}-\mathrm{O}$ catalytic system. The catalytic active phase was obtained by the citrate method with high specific surface area and excellent homogeneity. A solid solution between $\mathrm{Mn}_{2} \mathrm{O}_{3}-\mathrm{Fe}_{2} \mathrm{O}_{3}$ was observed. As iron is located into the bixbyite structure of the $\mathrm{Mn}_{2} \mathrm{O}_{3}$, the catalytic performance was strongly improved with respect to pure oxides ${ }^{20}$. The Fe-Mn system was also studied by co-precipitation in ammonium hydroxide. Over $500^{\circ} \mathrm{C}$ calcination, the specific surface area decreases remarkably and, thus, the catalytic performance. A smal amount of $\mathrm{Fe}$ is enough to favour the presence of dispersed Mn-oxide species, $\mathrm{MnOx}$, that are more easily reducible ${ }^{27}$.

The industrial application of VOC catalytic combustion process involves great volumes of gases, therefore, it is essential to deposit the catalyst on structured support to avoid high pressure drops. The most studied supports are monoliths, which are usually made of ceramic or metal materials, covered with a carrier, alumina, which acts as a support of the active phase ${ }^{28}$. For the process design, the energy balance is taken into account. Security regulations indicate that the combustion catalytic systems should not be used when concentration of VOCs in the stream to be treated exceeds $25 \%$ of lower explosive limit (LEL). At low concentration of VOCs, the stream needs to be heated but the gas temperature is lower than that for thermal oxidation. Metallic monolithic catalysts may be used as an electrically resistive element with the objective of heating the reactor. Their higher price is compensated by different properties such as their higher mechanical resistance, lightness, better thermal conductivity and lower thermal inertia. Several metals and alloys have been proposed to prepare monoliths, being Fecralloy ${ }^{\circledR}$ the most usual. It is a ferritic stainless steel alloy containing $\mathrm{Fe}, \mathrm{Cr}$ and Al. Fecralloy ${ }^{\circledR}$ presents excellent properties because, after an appropriate pre-treatment, an alumina protecting layer is produced with excellent characteristics for anchoring the catalytic coating ${ }^{29-30}$. Austenitic stainless steel becomes an interesting alternative to the use of Fecralloy ${ }^{\circledR}$ substrate for the manufacturing of metallic monoliths, since it is cheaper and can be used at temperatures as high as $750{ }^{\circ} \mathrm{C}$. Thus, it might be used at the normal temperatures expected in environmental catalytic processes. As Fecralloy ${ }^{\circledR}$, austenitic steel does not have a rough surface. Roughness could be obtained by thermal treatments ${ }^{31-33}$.

After the thermal treatment, AISI 304 stainless steel shows a good surface morphology. The oxide layer, rich in $\mathrm{Cr}$ and $\mathrm{Mn}$, with different sizes of crystals and good adherence to the substrate has a texture able to retain catalyst particles. Both in situ generation of the catalyst and chemical affinity with the oxide layer are possible ${ }^{33}$. Although a thermal treatment generates a rough surface suitable for a physic and chemical anchoring of the catalyst, it is interesting to study the incorporation of a support. The function of the alumina as a the most used commercial support facilitates the dispersion and stability of the catalytic phase. This support should have a high specific surface area, adequate distribution of pore size and good thermal stability. The objective of this work is to synthetize a Mn-Fe-O catalyst on the surface of a thermally treated stainless steel, for the total combustion of VOCs. This goal is intended to be achieved with the addition of $\mathrm{Fe}$ and $\mathrm{Mn}$ from their corresponding nitrates in a 1:3 Fe/Mn ratio, trying to reproduce the excellent performance of the bulk catalyst ${ }^{20}$. This work is aimed at studying the formation of the active phase, as well as the dispersion and chemical affinity of the phase with the support. These factors are crucial for a good catalytic performance and stability of the formed catalyst.

To deposit the active phase on the support surface, the wet impregnation method was used. This method favours a close solid-liquid interaction, and hence, high loads of active phase may be obtained. It is expected that the active phase will be in the form of particles strongly anchored to the surface of the metallic supports. Moreover, the aim is also to capitalize the support-precursor interaction by means of acid-base centres, as well as the presence of $\mathrm{Mn}$ (II) cations on the surface of the oxide layer formed on calcination of steel in air flow ${ }^{29,34}$.

\section{EXPERIMENTAL}

\subsection{Preparation of the catalysts}

\subsubsection{Preparation of the monoliths}

An AISI 304 stainless steel was provided by Goodfellow with a thickness of $0.05 \mathrm{~mm}$, with composition: $\mathrm{Cr} 19 \%$, Ni $9.2 \%, \mathrm{Mn} \%, \mathrm{C}<0.08 \%$, and the balance of $\mathrm{Fe}$. Monoliths were prepared by rolling around a spindle alternate flat and corrugated sheet. The final monolith is a cylinder of $16 \mathrm{~mm}$ diameter, $30 \mathrm{~mm}$ height and a cell density of $60 \mathrm{cell} / \mathrm{cm}^{2}{ }^{33}$. AISI 304 stainless steel 
samples were washed with water and detergents, then washed with acetone, and finally were dried in air flow. The monoliths were thermally treated to produce a surface composition and roughness convenient in the conditions described in Durán et al. ${ }^{33}$. The thermal treatment was performed in a quartz tubular reactor with $16 \mathrm{ml} / \mathrm{min}$ flow of synthetic air (Air liquid 99.999 pure). Monoliths were heated from room temperature to $900{ }^{\circ} \mathrm{C}$ at $10{ }^{\circ} \mathrm{C} \mathrm{min}-1$, maintained 120 min at this temperature and then, cooled down to room temperature under the same atmosphere. The thermally treated monolith before the impregnation process was called 2A900a.

\subsubsection{Deposition of colloidal alumina on the treated monoliths}

The thermally treated monoliths were immersed in a suspension of pure colloidal alumina $\left(\mathrm{Nyacol}^{\mathbb{}}{ }^{\mathrm{D}}\right.$ suspension $\mathrm{Al} 20$ ). The monoliths were immersed during one minute and withdrawn at a constant speed of $3 \mathrm{~cm} \mathrm{~min}^{-1}$. To avoid obstruction of the monoliths channels, the excess of colloid was removed by blowing air at 6 psig during 40 seconds. Three immersions were performed and after each one, the coated monoliths were dried at $120^{\circ} \mathrm{C}$ for 1 hour and were calcined at $500{ }^{\circ} \mathrm{C}$ for 3 hours. The monolith with 3 alumina dives was called Al3.

\subsubsection{Catalysts preparation}

For the impregnation with manganese nitrate and iron nitrate, $\mathrm{Mn}\left(\mathrm{NO}_{3}\right)_{2} \cdot 4 \mathrm{H}_{2} \mathrm{O}$ and $\mathrm{Fe}\left(\mathrm{NO}_{3}\right)_{3} \cdot 9 \mathrm{H}_{2} \mathrm{O}$ in 1:3 ratio of Fe:Mn, an aqueous solution of $\mathrm{MnN}_{2} \mathrm{O}_{2} \cdot 4 \mathrm{H}_{2} \mathrm{O}$ (Fluka) $9,95 \mathrm{M}$ and an aqueous solution $\mathrm{Fe}\left(\mathrm{NO}_{3}\right)_{3} \cdot 9 \mathrm{H}_{2} \mathrm{O}$ (Fluka) 6,16 M, were used. The monoliths with and without alumina were immersed in the solution and stirred for orbital agitation. To avoid clogging of the channels of monoliths, the excess solution was removed by blowing air at 6 psig for 40 seconds. Three immersions were made and after that, each impregnated monolith obtained was dried at $80{ }^{\circ} \mathrm{C}$ for 24 hours and calcined at $500^{\circ} \mathrm{C}$ for 3 hours preventing stripping. The drying process was performed slowly to avoid formation of bubbles and agglomerates.

The samples were named as follows:

- IFeMnX, monoliths impregnated with manganese nitrate and iron nitrate, where $\mathrm{X}: 1,2$ and 3 is the number of impregnations.

- Al3FeMnX, monoliths with alumina impregnated with manganese nitrate and iron nitrate, where $\mathrm{X}: 1,2$ and 3 is the number of impregnations.

\subsection{Characterization}

\subsubsection{X-ray diffraction (XRD)}

XRD patterns were obtained by using a Rigaku diffractometer operated at $30 \mathrm{kV}$ and $25 \mathrm{~mA}$ and by employing V-filtered $\mathrm{Cr} \mathrm{K} \alpha$ radiation $(\lambda=0.2291 \mathrm{~nm})$ in continuous scan mode from $30^{\circ}$ to $140^{\circ}$ of $2 \theta$ using sampling interval of $0.05^{\circ}$. The crystalline phases were identified by reference to powder diffraction data. The XRD characterization was performed on a sheet of stainless steel used as reference sample. This sheet of stainless steel was thermally treated with the monolith, and was impregnated in the same conditions of the monolith.

\subsubsection{Scanning Electron Microscopy (SEM)}

The morphology of study samples was examined with a scanning electron microscope LEO 1450VP. The samples were covered with a thin gold layer to improve image quality. The SEM characterization was performed on a sheet of stainless steel used as reference. This sheet of stainless steel was thermally treated with the monolith, and was impregnated in the same conditions of the monolith.

\subsubsection{Adherence test}

The adherence of the coatings obtained in monoliths was evaluated in terms of the weight loss by ultrasound. The coated monoliths were immersed in $25 \mathrm{ml}$ petroleum ether, and then treated in an ultrasound bath for $30 \mathrm{~min}$. The sample after ultrasonic treatment was dried for 1 hour at $120^{\circ} \mathrm{C}$. In these conditions, the mass of solvent that remained in the sample was not significant. The weight loss is presented as percentage of the total coating ${ }^{35}$. Adhesion test was performed on monoliths.

\subsubsection{BET surface area measurements $\left(S_{B E T}\right)$}

The surface area was studied by $\mathrm{N}_{2}$ adsorption measurements at liquid nitrogen temperature in a Micromeritics Gemini V apparatus with a homemade cell in order to analyse the whole monolith.

\subsubsection{Temperature-programmed reduction (TPR)}

The TPR was performed in a quartz U-type tubular reactor using a TCD as detector. A $25 \mathrm{mg}$ sample was used. This sample was a powder obtained by scraping the monolith. The reducing gas was a mixture of $5 \mathrm{vol} . \% \mathrm{H}_{2} / \mathrm{N}_{2}$, at a total flow rate of $30 \mathrm{ml} \mathrm{min}^{-1}$. The temperature was increased at a rate of 10 ${ }^{\circ} \mathrm{C}$ minn $^{-1}$ from room temperature to $700{ }^{\circ} \mathrm{C}$; then, it was kept constant at $700{ }^{\circ} \mathrm{C}$ until the signal of hydrogen consumption returned to the initial values.

\subsection{Catalytic test}

The monolith was evaluated in the complete combustion of ethyl acetate The reacting stream was $300 \mathrm{~cm}^{3} \mathrm{~min}^{-1}$ with a composition of $4000 \mathrm{mg} \mathrm{C}$ $\mathrm{m}^{-3}$ diluted in synthetic air. The space velocity was $3750 \mathrm{~h}-1$ The gaseous mixture was analysed before and after reaction by gas chromatography using a Buck Scientific Mod 910 equipped with a FID detector, a methanizer and a Carbowax 20M/Chromosorb W column. The obtained data were the average of two results in stationary state.

\subsection{Stability test}

The stability of IFeMn3 y Al3FeMn3 monolithic catalysts was evaluated with an aging test. Monoliths were evaluated in the ethyl acetate combustion during $40 \mathrm{~h}$ at $320^{\circ} \mathrm{C}$. This temperature is higher than ethyl acetate total combustion temperature. After the aging test, monoliths were evaluated in ethyl acetate combustion. The results are expressed as intrinsic activity in $\mathrm{mol} / \mathrm{g} * \mathrm{~h}$.

\section{RESULTS}

\subsection{Mass Gain}

Table 1. Mass gain after impregnation, mass loss during the adherence test, surface, $\mathrm{T}_{80}$ and area per monolith $\left(\mathrm{S}_{\mathrm{BET}}\right)$.

\begin{tabular}{|c|c|c|c|c|}
\hline $\begin{array}{l}\text { Monolith } \\
\text { catalyst }\end{array}$ & $\begin{array}{c}\text { Mass gain } \\
\text { of active } \\
\text { phase (\%) }\end{array}$ & $\begin{array}{l}\text { Mass loss } \\
\text { (Adherence } \\
\text { test \%) }\end{array}$ & $\underset{\left(\mathbf{m}^{2} \mathbf{m o n o l}^{-1}\right)}{\mathrm{S}_{\mathrm{BET}}}$ & $\begin{array}{l}\mathbf{T}_{80} \\
\left({ }^{\circ} \mathbf{C}\right)\end{array}$ \\
\hline IFeMn1 & $2.6 \pm 0.6$ & 1.5 & n.d. & 304 \\
\hline $\mathrm{IFeMn} 2$ & $5.8 \pm 0.8$ & 0.5 & n.d. & 250 \\
\hline IFeMn3 & $9.3 \pm 0.4$ & 0.5 & n.d. & 240 \\
\hline $\mathrm{A} 13 \mathrm{FeMn} 1$ & $1.9 \pm 0.5$ & $2.5^{*}$ & 34.3 & 269 \\
\hline $\mathrm{A} 13 \mathrm{FeMn} 2$ & $4.5 \pm 0.5$ & $0.9^{*}$ & & 265 \\
\hline $\mathrm{Al} 3 \mathrm{FeMn} 3$ & $7.8 \pm 0.1$ & $0.4^{*}$ & 38.8 & 250 \\
\hline 2A900a & & & n.d. & 370 \\
\hline $\mathrm{A} 13$ & & & 62.3 & 322 \\
\hline
\end{tabular}

Table 1 shows the mass gain in subsequent impregnations with iron and manganese nitrates. On IFeMnx and Al3FeMnx supports, a linear increase of mass gain with the number of impregnations (Figure 1) is observed. The monoliths Al3FeMnx gained a lower percentage of mass in comparison with those without alumina - FeMnx. Clearly, the percentage of mass gain was higher in IFeMnx than in Al3FeMnx.

\subsection{Adherence test}

The mass loss after the adherence test (Table 1) shows that Al3FeMnx monoliths lost a higher amount of total mass which involved the alumina and the active phase. Figure 2 shows the mass loss of monoliths IFeMnx and Al3FeMnx. As the number of impregnations increased, the mass loss decreased. In monoliths Al3FeMnx, this trend was more marked than in IFeMnx. The mass loss in monolith Al3FeMn1 was higher than in IFeMnx, in spite of gaining a similar mass after nitrate impregnation. However, this behaviour was not so evident with 2 and 3 impregnations. 


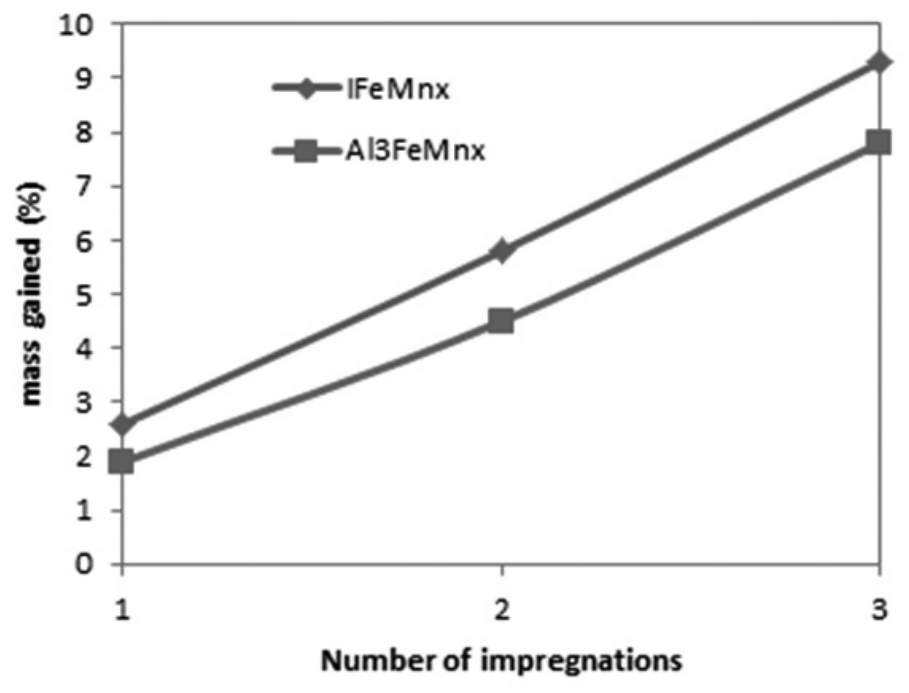

Figure 1: Mass gain vs. number of impregnations.

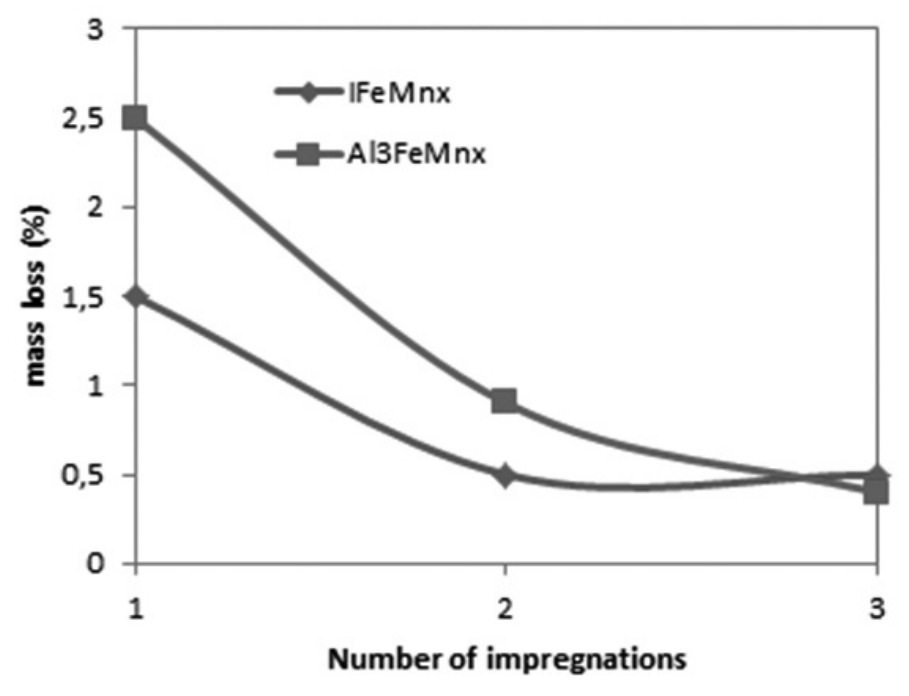

Figure 2: Mass loss during the adherence test vs number of impregnations.

\subsection{X-ray diffraction (XRD)}

Figure 3 shows the diffractograms of monoliths 2A900a and Al3. The diffraction lines of the austenite phase (PDF 31-0619) and the $\mathrm{C}_{0.055} \mathrm{Fe}_{1.945}$ phase (PDF 44-1290) present in the steel with thermal treatment ${ }^{33}$ are observed in sample A13. The main signals of the austenite phase are in angles $2 \theta: 66.78^{\circ}$, $78.99^{\circ}$ and $128.7^{\circ}$. The phases generated by thermal treatment, $\mathrm{Cr}_{2} \mathrm{O}_{3}$ (PDF 1-84-1616) and $\mathrm{Mn}_{1} \mathrm{Cr}_{2} \mathrm{O}_{4}$, are also observed in monolith $\mathrm{A} 13$, although with less intensity. The only diffraction line slightly detected in monolith A13 is the most intense of the $\delta-\mathrm{Al}_{2} \mathrm{O}_{3}$ phase (PDF 16-394).

In Figure 4, the diffractogram of the family of monoliths IFeMnx is shown. The characteristic phases of AISI 304 steel are the austenite phase (PDF 31-0619) and the $\mathrm{C}_{0.055} \mathrm{Fe}_{1945}$ iron-carbon phase (PDF 44-1290) which are present in all the samples. The diffraction lines of $\mathrm{Mn}_{2} \mathrm{O}_{3}$ phase (PDF 41-1442) increased their intensity with the number of impregnations; while the $\mathrm{Cr}_{2} \mathrm{O}$ (PDF 1-84-1616) and $\mathrm{Mn}_{+\times} \mathrm{Cr}_{2-x} \mathrm{O}_{4-x}$, phases kept the same intensity of the diffraction lines with successive impregnations.

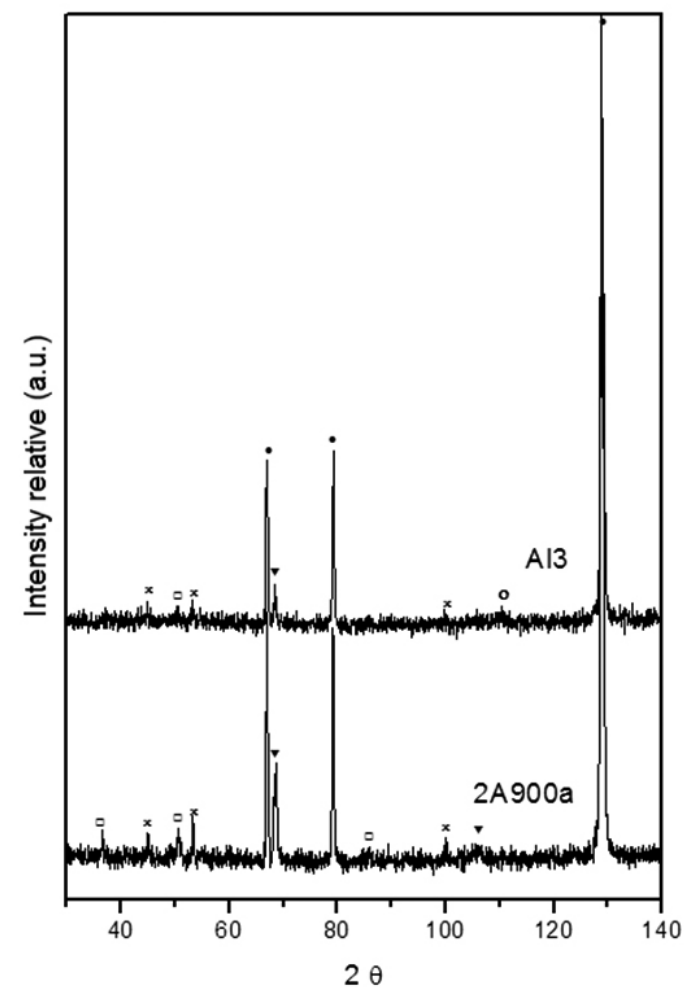

Figure 3: XRD patterns of base monolith (2A900a) and monolith with 3 impregnations of alumina (Al3). Phases: $(\bullet)$ austenite, $(\boldsymbol{\nabla}) \mathrm{C}_{0.055} \mathrm{Fe}_{1.945}(\mathrm{PDF}$ 44-1290), (口) $\mathrm{Cr}_{2} \mathrm{O}_{3}$ (PDF 1-84-1616), (X) $\mathrm{Mn}_{1+\mathrm{x}} \mathrm{Cr}_{2-\mathrm{x}} \mathrm{O}_{4-\mathrm{x}}$, (o) $\delta_{-155}-\mathrm{Al}_{2} \mathrm{O}_{3}$ (PDF 16-394).

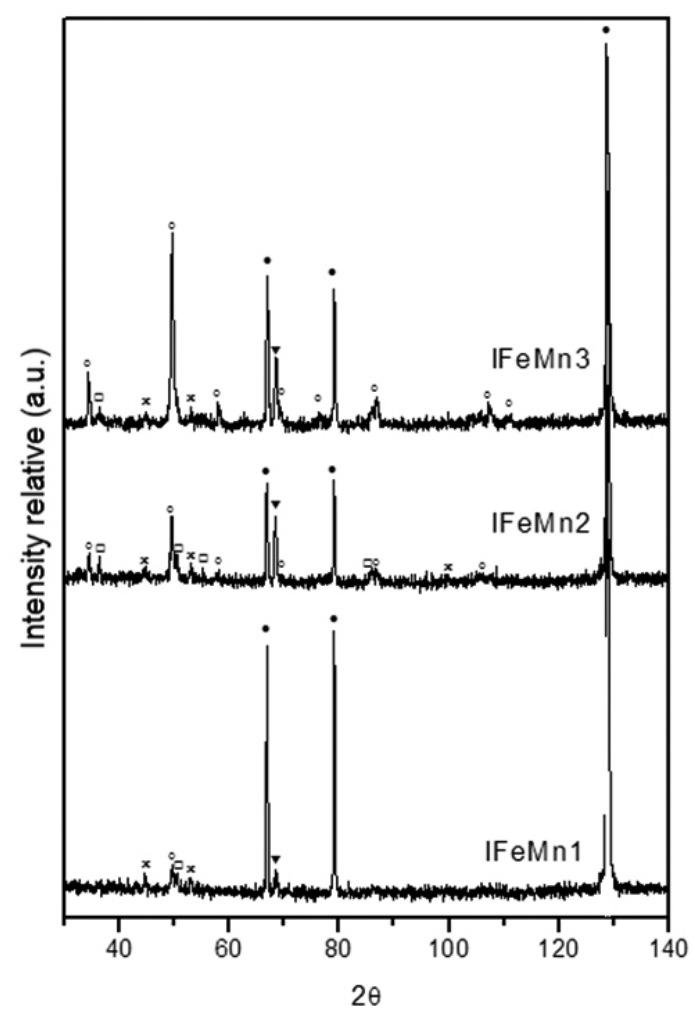

Figure 4: XRD patterns of monoliths IFeMnx. Phases: $(\bullet)$ austenite, $(\boldsymbol{\nabla})$ $\mathrm{C}_{055} \mathrm{Fe}_{1045}\left(\mathrm{PDF}\right.$ 44-1290), (ㅁ) $\mathrm{Cr}_{2} \mathrm{O}_{3}$ (PDF 1-84-1616), (X) $\mathrm{Mn}_{1+\mathrm{x}} \mathrm{Cr}_{2-\mathrm{O}} \mathrm{O}_{4-}$, (O) $\mathrm{Mn}_{2} \mathrm{O}_{3}$ (PDF 41-1442). 
3.4. Scanning Electron Microscopy (SEM-EDS)

\section{Microphotograph}

Figure 6 shows micrographs of the surface of monoliths IFeMnx. In monolith IFeMn1, a homogenous coating of the surface by the impregnated phase is observed. Monolith IFeMn2 shows a homogenous coating with certain protuberances on the surface. These imperfections may be related to the drying and calcination procedure. On the other hand, monolith IFeMn3 presents the small crystals distributed throughout the surface.
Furthermore, Figure 7 shows the microphotographs of Al3FeMnx surface. In monolith A13, a homogenous surface without imperfections or crystal formation is observed. In general, this monolith shows a homogenous distribution of the impregnated phase on the entire surface without observable evidence by SEM of crystal formation.

In Figure 5, the XRD diagrams of family of monoliths Al3FeMnx are observed. The diffraction lines of $\mathrm{Mn}_{2} \mathrm{O}_{3}$ and $\mathrm{Mn}_{1+\mathrm{x}} \mathrm{Cr}_{2-\mathrm{x}} \mathrm{O}_{4-\mathrm{x}}$ phases are barely detected as those of $\mathrm{Cr}_{2} \mathrm{O}_{3}$ phase.

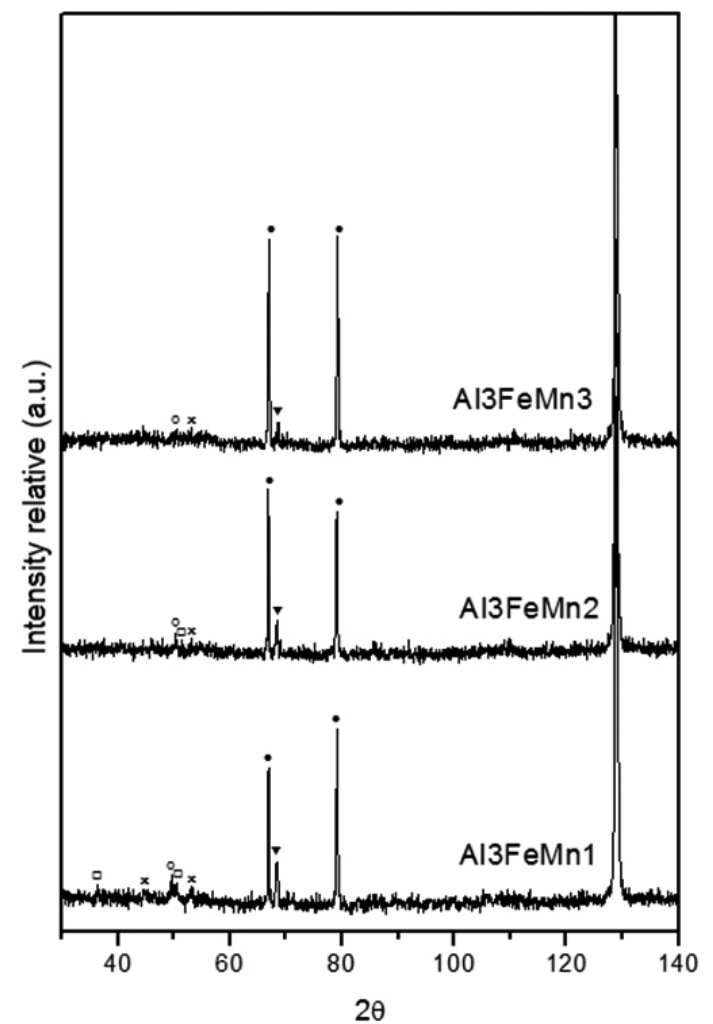

Figure 5: XRD patterns of monoliths Al3FeMnx Phases: $(\bullet)$ austenite, $(\boldsymbol{\nabla}) \mathrm{C}_{0055} \mathrm{Fe}_{1.945}$ (PDF 44-1290), ( $\square$ ) $\mathrm{Cr}_{2} \mathrm{O}_{3}$ (PDF 1-84-1616), (X) $\mathrm{Mn}_{1+\mathrm{x}} \mathrm{Cr}_{2-\mathrm{x}} \mathrm{O}_{4-\mathrm{x}},(\mathrm{O}) \mathrm{Mn}_{2} \mathrm{O}_{3}$ (PDF 41-1442).
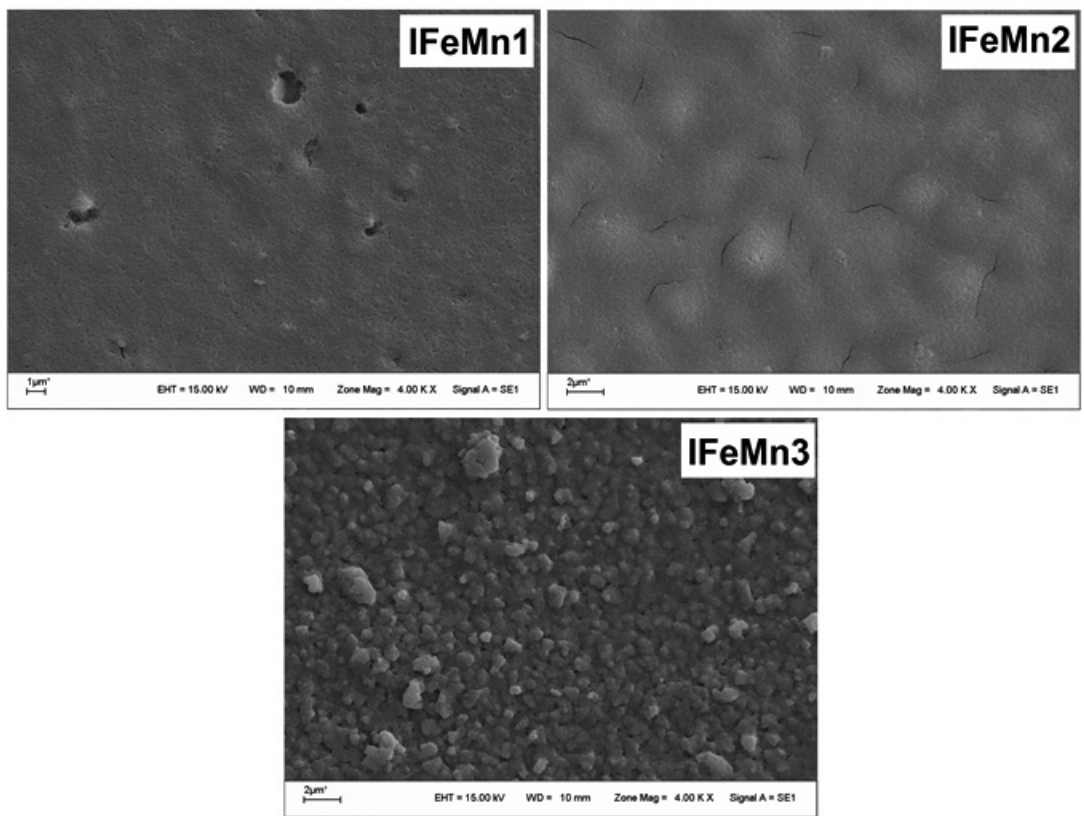

Figure 6: SEM micrographs, increased 4kx. Monoliths IFeMnx. 


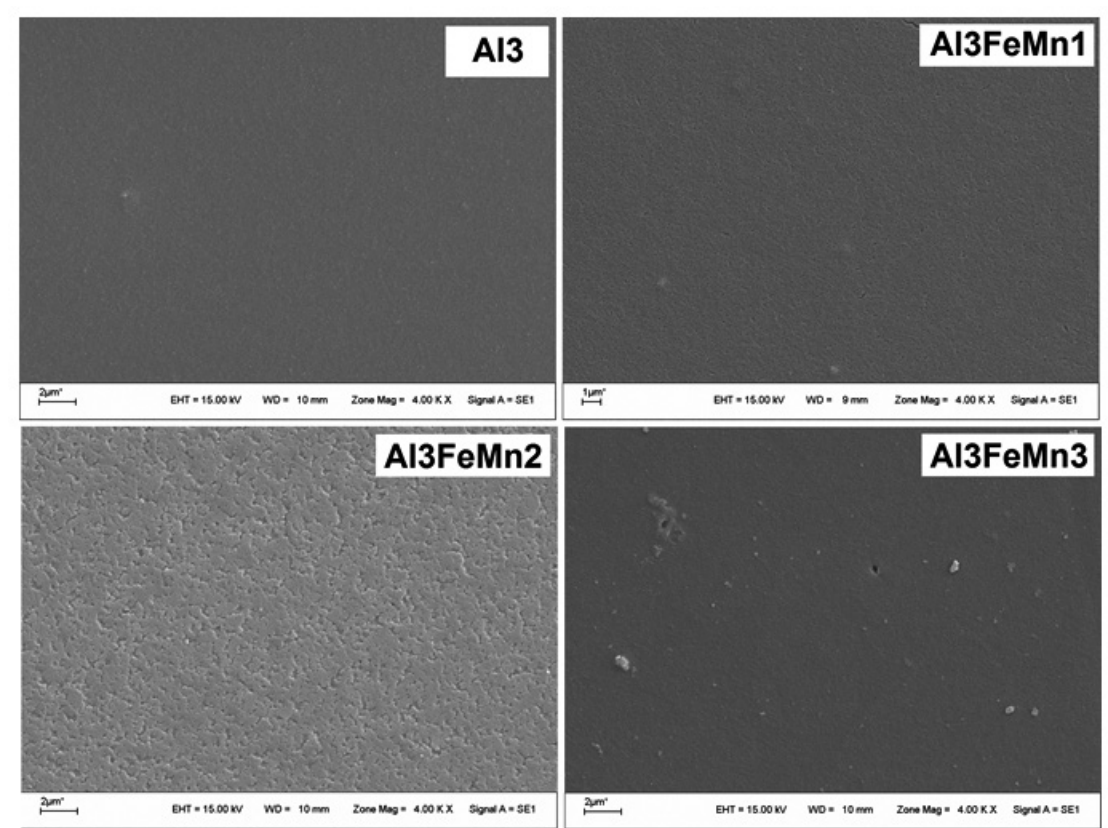

Figure 7. SEM micrographs, increased 4kx. Monoliths Al3FeMnx and Al3.

Mapping

In Figure 8, the mapping of $\mathrm{Cr}, \mathrm{Fe}$ and $\mathrm{Mn}$ on the surface of monoliths Al3FeMn 1, 3 and IFeMn1, 3 is shown. In the monoliths without alumina, the presence of $\mathrm{Cr}$ decreased in density as a higher load of the impregnated phase and Fe-Mn increased. In the case of the monoliths impregnated with alumina, the presence of $\mathrm{Cr}$ was less than the rest of the elements due to the fact that it was covered by 3 layers of alumina. Nevertheless, it is detectable, while with $\mathrm{Fe}$ and $\mathrm{Mn}$, a slight increase is observed as the load increases.

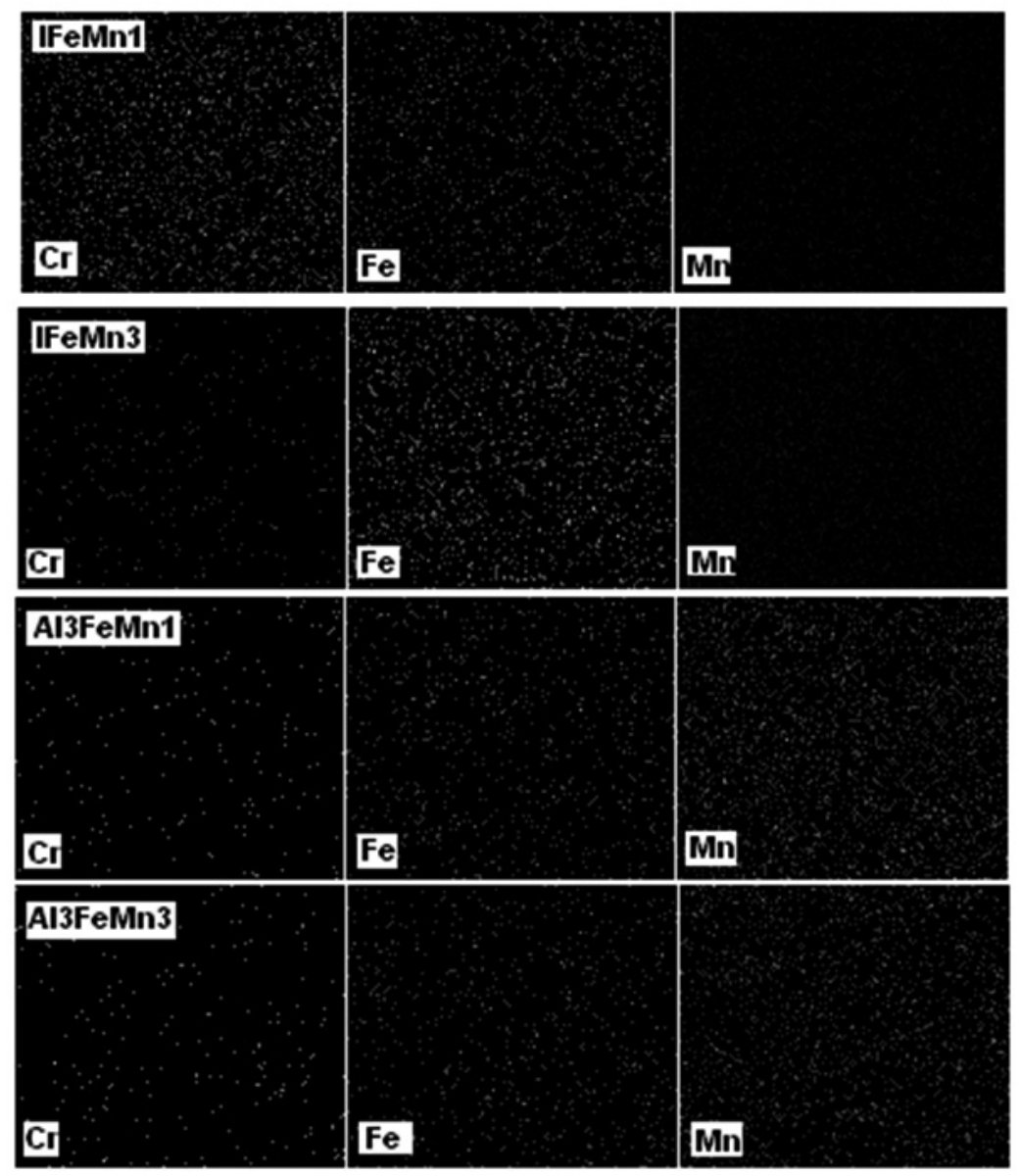

Figure 8. Mapping the surface of monoliths Al3FeMn1-3 and IFeMn1-3. 


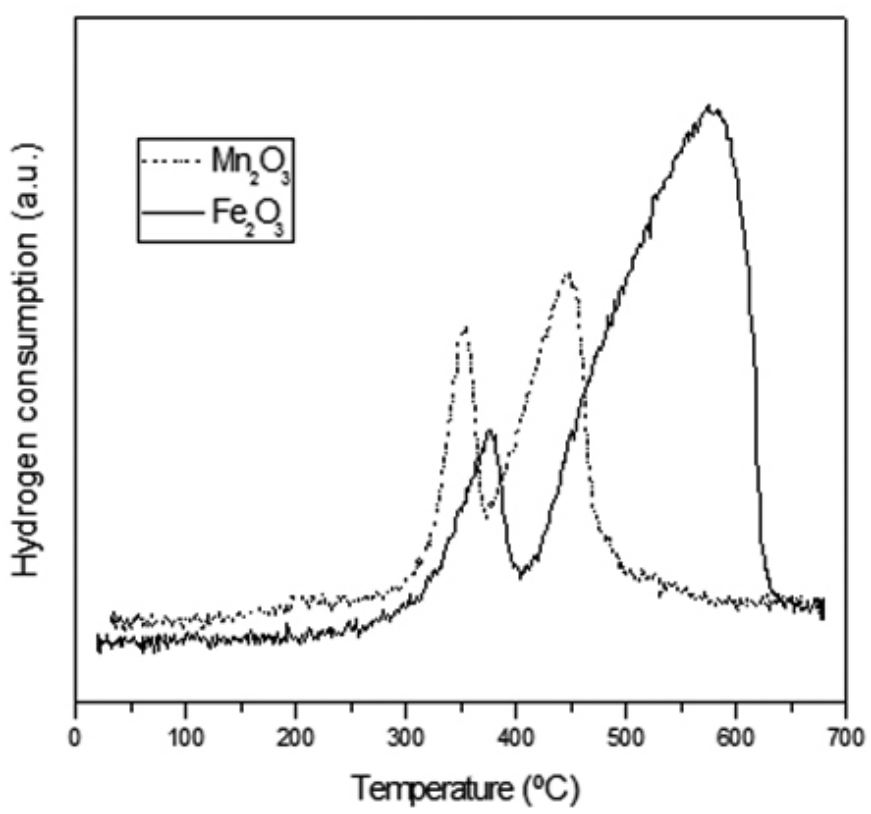

Figure 9. Temperature-programmed reduction profile of pure oxides, $\mathrm{Fe}_{2} \mathrm{O}_{3}$ and $\mathrm{Mn}_{2} \mathrm{O}_{3}$.

\subsection{Temperature-programmed reduction (TPR)}

In Figures 10 and 11, the reduction profiles of monoliths IFeMn3 and Al3FeMn3 are shown. In both profiles, four signals can be observed although in the former, they are better defined (two weak signals at $240{ }^{\circ} \mathrm{C}$ and 616 ${ }^{\circ} \mathrm{C}$ and two very intense at $390{ }^{\circ} \mathrm{C}$ and $505^{\circ} \mathrm{C}$ ) than in the latter (two intense signals at $375^{\circ} \mathrm{C}$ and $433^{\circ} \mathrm{C}$, a shoulder at $479{ }^{\circ} \mathrm{C}$, and a weak one at $586{ }^{\circ} \mathrm{C}$ ).

All these peaks of $\mathrm{H}_{2}$ consumption may be attributed to the reduction of iron, manganese or, to a lesser extent, to chrome species. With respect to IFeMn3, the two large peaks observed might be the result of the overlapping of the peaks of different oxides. The first peak at $390{ }^{\circ} \mathrm{C}$ may be attributed to the combination of the reduction profiles for $\mathrm{Fe}_{2} \mathrm{O}_{3}$ to $\mathrm{Fe}_{3} \mathrm{O}_{4}$, and $\mathrm{Mn}_{2} \mathrm{O}_{3}$ to $\mathrm{Mn}_{3} \mathrm{O}_{4}$. The second peak at $505{ }^{\circ} \mathrm{C}$ may be due to the reduction of $\mathrm{Fe}_{3} \mathrm{O}_{4}$ to $\mathrm{FeO}$, and $\mathrm{Mn}_{3} \mathrm{O}_{4}$ to $\mathrm{MnO}^{36-39}$.

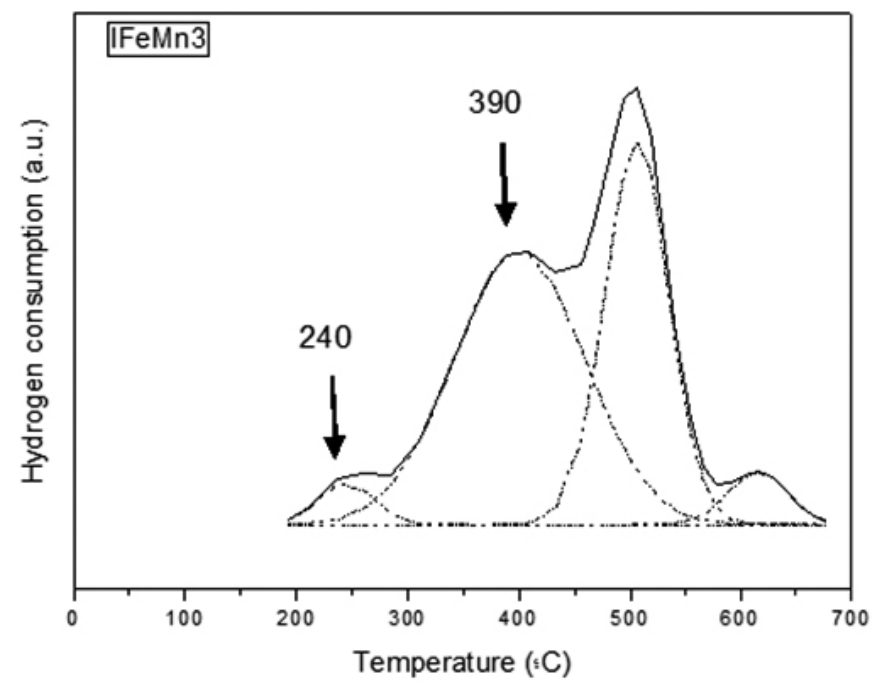

Figure 10. Temperature-programmed reduction profiles for IFeMn3.

A similar behaviour may be observed in the case of Al3FeMn3, although it is worth noting that the first two reduction peaks were at higher temperatures than the last two which were at lower temperatures. The hydrogen consumption of monoliths Al3FeMn3 and IFeMn3 was of 5,8 $\mu \mathrm{mol} \mathrm{mg} \mathrm{cat}{ }^{-1}$ and 4,45 $\mu \mathrm{mol}$ $\mathrm{mg} \mathrm{cat}^{-1}$, respectively.

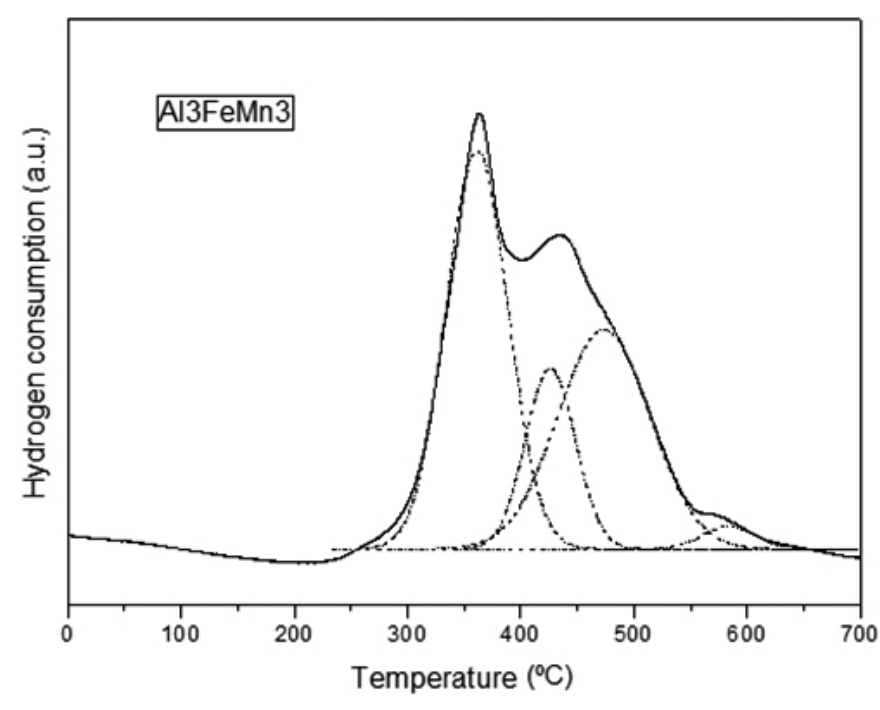

Figure 11. Temperature-programmed reduction profiles for Al3FeMn3.

3.6. BET surface area measurements $\left(S_{B E T}\right)$

The values obtained from the BET surface area of monoliths A13FeMnx are presented in Table 1. In monolith 2A900a as in monoliths IFeMnx, the surface area, $\mathrm{S}_{\mathrm{BET}}$, was not measured, probably because it is $<1 \mathrm{~m}^{2}$ monolith $^{-1}$.

Once the monolith was impregnated with a thermal treatment of three alumina loads, $\mathrm{Al} 3$, the surface area $\mathrm{S}_{\mathrm{BET}}$ /monolith increased considerably, to the value of $62.3 \mathrm{~m}^{2} \mathrm{mon}^{-1}$, as expected. The subsequent impregnations with precursors of $\mathrm{Fe}$ and $\mathrm{Mn}$ caused a decrease of this surface area. This value is almost the half of A13. The surface area per monolith of A13FeMn3 is only 4 $\mathrm{m}^{2}$ more than A13FeMn1.

\subsection{Catalytic test}

The results of the catalytic activity represented by the temperature at which the ethyl acetate conversion is of $80 \%, \mathrm{~T}_{80}$, are shown in Table 1 . Figure 12 shows the complete conversion curves as a function of the reaction temperature.

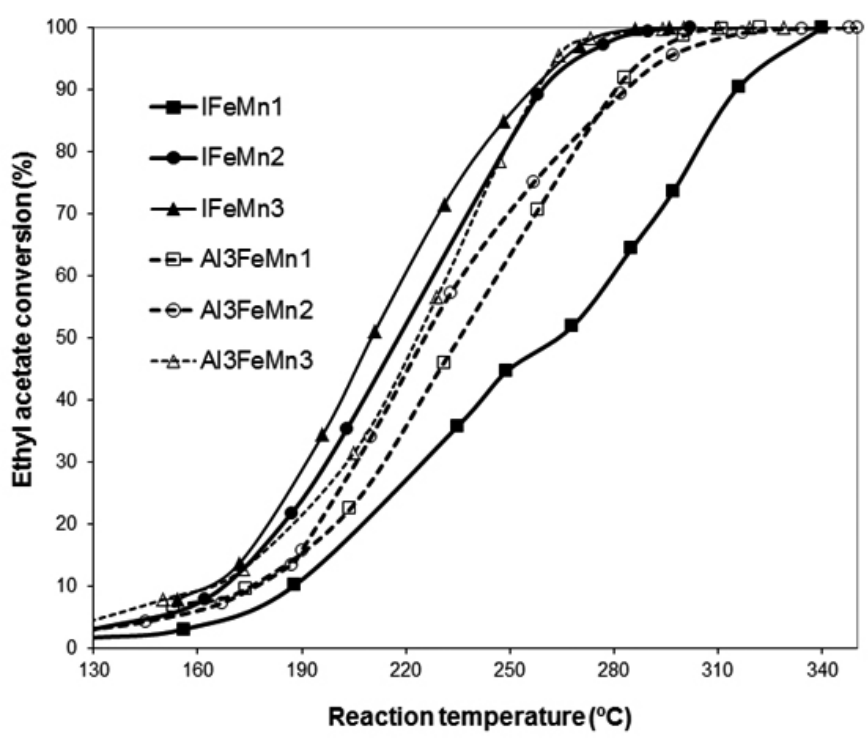

Figure 12. Curves of catalytic activity in ethyl acetate combustion.

The catalytic behaviour of each series, analysed independently from the other is in line with the increase of the active phase. Thus, the monoliths with three loads of active phase are those which presented the best catalytic performance of each series of monoliths, being IFeMn3 the most active, and 
IFeMn2 as active as Al3FeMn3. The catalytic sequence of $\mathrm{T}_{80}$ was IFeMn3 $>$ IFeMn2 $\approx \mathrm{Al} 3 \mathrm{FeMn} 3>\mathrm{Al} 3 \mathrm{FeMn} 2>\mathrm{Al} 3 \mathrm{FeMn} 1>\mathrm{IFeMn} 1$.

\subsection{Stability test}

In order to analysed the stability of monolithic catalysts under reaction conditions, an aging test of IFeMn3 y Al3FeMn3 monoliths was performed. The intrinsic activity versus reaction temperature curves obtained before and after the aging test are presented in Figure 13.
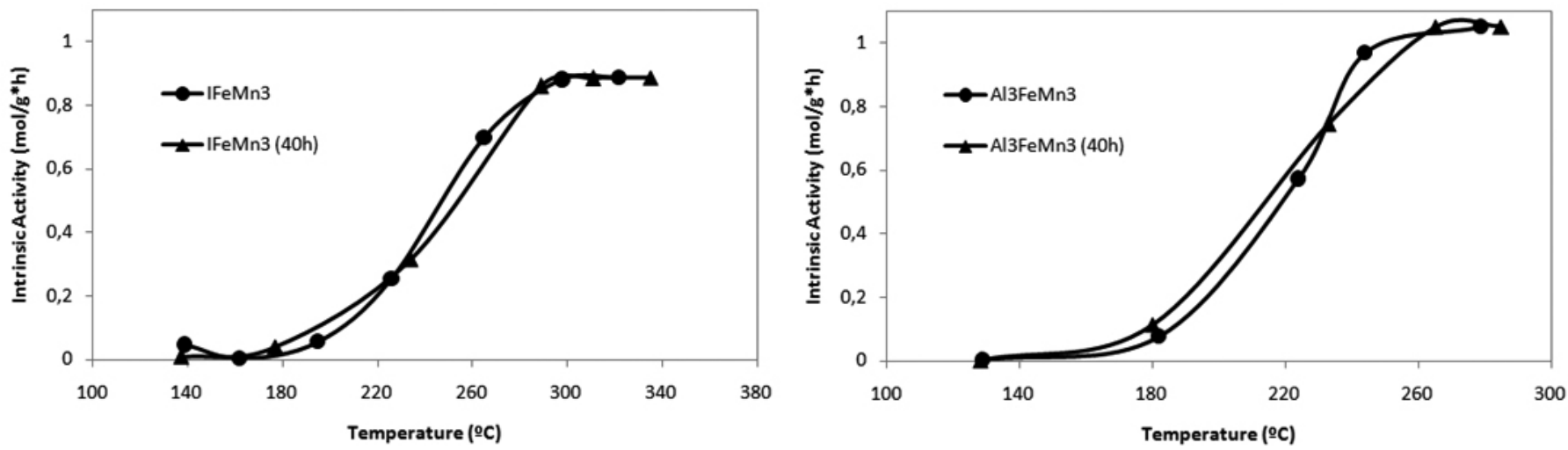

Figure 13. Curves of activity intrinsic in ethyl acetate combustion.

As it is observed, the catalytic activity after $40 \mathrm{~h}$ on stream under severe conditions did not change. Both monoliths resulted highly stable.

\section{DISCUSSION}

The assumption that incorporating alumina as support would increase the specific surface area was corroborated, obtaining a stable monolith. $\mathrm{A} \mathrm{S}_{\mathrm{BET}}$ monolith of approximately $60 \mathrm{~m}^{2}$ monolith-1 was achieved, decreasing to values between 34 and $38 \mathrm{~m}^{2}$ monolith $^{-1}$ after impregnation with Fe and Mn. With the addition of alumina, a homogenous coating of the steel sheet thermally treated (Figure 7) was obtained. This coating is evidently porous in order to get to a $\mathrm{S}_{\text {PFT }}$ of approximately $60 \mathrm{~m}^{2} /$ monolith. However, its distribution forming a layer that levels the surface is highly homogenous. This thin layer is enough to attenuate the diffraction lines of steel sheet base 2A900a. As an example, the diffractograms of IFeMn3 are very different from those of $\mathrm{Al} 3 \mathrm{FeMn} 3$, although a similar mass gain of the impregnated phase, 518 and $458 \mathrm{mg}$, respectively, has been obtained. After the adherence test, the values of mass loss are acceptable; however, in the family Al3FeMnx, the loss is higher but within this mass loss, the active phase of support cannot be discriminated because it includes the alumina. Nevertheless, all the values of mass loss are acceptable for metallic monoliths, and the catalyst load with the successive impregnations follows a curve similar in both supports. The incorporated amounts of catalyst are also similar. The distribution of the elements which constitute $\mathrm{Fe}$ and Mn catalysts shows a high homogeneity (Figure 8 ) in both cases. The dissimilar specific surface area of the two supports $-2 \mathrm{~A} 900 \mathrm{a}\left(<1 \mathrm{~m}^{2}\right.$ monolith $\left.^{-1}\right)$ and $\mathrm{Al}\left(62 \mathrm{~m}^{2}\right.$ monolith $^{-1}$ ) - leads to assume that the added $\mathrm{Mn}-\mathrm{Fe}-\mathrm{O}$ will not have the same crystalline arrangement in both cases. In fact, the SEM images of the surface area are very different. The impregnated $\mathrm{Mn}$ and $\mathrm{Fe}$ on $\mathrm{Al} 3$ seems to copy the surface, although the $\mathrm{S}_{\mathrm{F}}\left(\sim 63\right.$ a $34 \mathrm{~m}^{2}$ monolith $\left.^{-1}\right)$ decreases. Apparently, once the monolayer is covered no crystal segregation on $\mathrm{Al} 3$ was observed; but the smaller $\mathrm{S}_{\mathrm{BET}}$ of $2 \mathrm{~A} 900$ a surface indeed generates crystals observable by the SEM microphotographs. The diffraction of X-rays corroborates these observations, showing for IFeMnx a progression of intensity of the $\mathrm{Mn}_{2} \mathrm{O}_{3}$ diffraction lines with the successive impregnations, while for $\mathrm{Al} 3$ as well as for the rest of the samples, only the main diffraction lines of the $\mathrm{Mn}_{2} \mathrm{O}_{3}$ (PDF 41-1442) with a very low intensity are observed.

The $\mathrm{Cr}$, as constituent of the steel, does not find an obstacle in the $\mathrm{Al}_{2} \mathrm{O}_{3}$ for its access to the surface. This cation migrates through the alumina to the surface. The direct contact in the surface between the $\mathrm{Cr}, \mathrm{Fe}$ and $\mathrm{Mn}$ leads to a more extended reaction in the support 2A900a in order to form the spine $\mathrm{Mn}_{1+\times} \mathrm{Cr}_{2 \times} \mathrm{O}_{4}$. This first description of the surface arrangements obtained with alumina might be summarized as follows: a) on the alumina, the $\mathrm{Mn}_{2} \mathrm{O}_{3}$ covers the surface in successive monolayers without segregation of $\mathrm{Mn}_{2} \mathrm{O}_{3}$ crystals, noticeable by SEM or XRD; b) the specific surface area per monolith is high, reaching $34 \mathrm{~m}^{2} /$ monolith. Furthermore, the multiphase arrangement without alumina includes crystals of $\mathrm{Cr}_{2} \mathrm{O}_{3}$ and $\mathrm{Mn}_{1+\mathrm{x}} \mathrm{Cr}_{2-\mathrm{x}} \mathrm{O}_{4-\mathrm{x}}$ without being their amount proportional to the load of Fe and Mn.

On monolith 2A900a, the surface arrangement of phases is more complex A smaller specific surface area does not prevent that the catalyst load is higher than on Al3. Nevertheless, the high ratio of Fe-Mn load to surface is evidenced in the segregation of $\mathrm{Mn}$ to form crystals of $\mathrm{Mn}_{2} \mathrm{O}_{3}$ with bixbyite structure. These crystals co-exist with the phases generated and/or segregated by the steel corrosion $-\mathrm{Cr}_{x} \mathrm{Fe}_{y}$ and $\mathrm{Cr}_{2} \mathrm{O}_{3}$. However, segregation of $\mathrm{Fe}_{2} \mathrm{O}_{3}$ is not observed although it should be present in $1 / 3$ of $\mathrm{Mn}_{2} \mathrm{O}_{3}$.

The results of $\mathrm{T}_{80}$ in the combustion of ethyl acetate show that the catalytic activity has the following order: $\mathrm{IFeMn} 3>\mathrm{IFeMn} 2 \approx \mathrm{Al} 3 \mathrm{FeMn} 3>$ $\mathrm{Al} 3 \mathrm{FeMn} 2>\mathrm{Al} 3 \mathrm{FeMn} 1>\mathrm{IFeMn} 1$. Specifically, the comparison of IFeMn3 with $\mathrm{Al} 3 \mathrm{FeMn} 3$ gives surprising results. Their loads of $\mathrm{Fe}-\mathrm{Mn}$ oxides are similar and their specific surface areas show a great difference (IFeMn $3<1$ $\mathrm{m}^{2} /$ monolith and Al3FeMn3 $39 \mathrm{~m}^{2} /$ monolith). Two factors may be affecting the catalytic activity in this magnitude, namely: a) the presence of $\mathrm{Mn}^{4+}$ eithe in species MnOx or in spinel, so the Mn may stabilize as $\mathrm{Mn}^{4+}$; and b) the existence of a Fe solid solution in the bixbyite $\mathrm{Mn}_{2} \mathrm{O}_{3}[20,26]$.

The XRD shows that spinel $\mathrm{Mn}_{1+x} \mathrm{Cr}_{2 \times x} \mathrm{O}_{4 \times}$ in comparison with the austenite phase, presents almost the same intensity in IFeMn1 as in IFeMn2 and IFeMn3. Although XRD is not quantitative, the samples under analysis have the same dimensions. Moreover, IFeMn3 has a higher amount of Mn as to capture all the $\mathrm{Cr}$ available facilitating, thus, the formation of $\mathrm{Mn}_{2} \mathrm{O}_{3}$. However, IFeMn3 shows a $T_{80}$ much lower than IFeMn1. The same effect is observed in the $\mathrm{Al} 3 \mathrm{FeMnx}$ series.

Although to a lesser degree than $\mathrm{Mn}$, the $\mathrm{Cr}$ cation results active in the oxidation reactions. Shen et al. ${ }^{40}$ studied the Fe-Mn system obtained by coprecipitation, and doped it with $\mathrm{Cr}$. Studying the TPR, they found that the Fe$\mathrm{Mn}$ reduction temperature shifted to lower values. Zhu et al. ${ }^{41}$ stated that the reduction of $\mathrm{Cr}^{3+}$ to $\mathrm{Cr}^{2+}$ occurred at $500{ }^{\circ} \mathrm{C}$, and that the $\mathrm{Fe}-\mathrm{Mn}$ reduction peaks not only ran at lower temperatures but also increased the areas beneath the curves with respect to pure oxides.

The reducible species, MnOx, present in IFeMn3 may have their origin in the portion of $\mathrm{Mn}$ that covers the surface, interacting strongly with it and has not migrated to $\mathrm{Mn}_{2} \mathrm{O}_{3}$ crystals as Shen et al. ${ }^{40}$ postulated.

The TPR technique is highly sensitive to characterize solids, and it has been extensively used for the study of surface and bulk of solid catalysts based on $\mathrm{Mn}^{25}$. In Figures 9, 10 and 11, the reduction profiles of pure oxides and of monoliths IFeMn3 y Al3FeMn3 are observed. Figure 10 shows the reduction profile of monolith IFeMn3 in which a peak at low temperatures associated with the easily reducible species $\left(\sim 240{ }^{\circ} \mathrm{C}\right)$ is clearly seen. It is well known that the $\mathrm{MnOx}$ species with defects in the net show a peak at low temperature in TPR experiments. Currently in the literature ${ }^{26}$, reducibility has been associated with combustion which is valid for $\mathrm{MnOx}$ species. However, the improvement of the catalytic activity of IFeMn3 may have an additional explanation.

The radii of $\mathrm{Fe}^{3+}$ and $\mathrm{Mn}^{3+}$ are $0.645 \AA$ for both ions, and the addition of $\mathrm{Fe}^{3+}$ in the bixbyite might re-arrange its structure, causing a decrease in the defects. 
Durán et al. ${ }^{20}$ described in detail the solid solution obtained with the catalyst $\mathrm{Mn} / \mathrm{Fe}$ synthesized by vitreous gelation. In this work, the addition of iron to the bixbyite structure promotes a resistance to the reduction of manganese oxide which is observable from the results of TPR. In fact, this phenomenon is observed in Figure 10. The first peak of reduction (transition $\mathrm{Mn}^{3+}$ to $\mathrm{Mn}^{3+}$ and $\mathrm{Mn}^{2+}$ ) shifted to higher reduction temperatures in IFeMn3; while in monolith A13FeMn3, this peak shifted to lower temperatures. Barroso Quiroga et al. ${ }^{42}$ observed a similar phenomenon in catalysts FeMnO synthesized by reactive milling.

\section{CONCLUSIONS}

The iron-manganese mixed monolithic catalysts were obtained by impregnation from nitrates as precursors. Monoliths of AISI 304 stainless steel with thermal treatment were used to generate roughness. Impregnation was carried out on these supports with: i) only the thermal treatment, and ii) with the same thermal treatment and an alumina layer deposited by impregnation. The latter show a higher specific surface area while in the monoliths without alumina, the area could not be measured because it was less than $1 \mathrm{~m}^{2}$ monolith ${ }^{-1}$. The main phase detected by DRX was the oxide $\mathrm{Mn}_{2} \mathrm{O}_{3}$. In the IFeMnx samples, this phase was more intense than in the family of Al3FeMnx. The fact that the mass gain in those monoliths without alumina is higher than in the family with alumina might suggest that there is a greater dispersion of the phase on the surface area of the alumina. The higher activity of IFeMnx with respect to A13FeMnx may be accounted for the formation of the solid solution where the $\mathrm{Fe}$ is introduced to the bixbyite structure. However, the presence of defective $\mathrm{MnOx}$ species in monoliths without alumina which might help to improve their performance is observed. Both IFeMn3 and Al3FeMn3 monoliths were stable after $40 \mathrm{~h}$ on stream at extreme conditions. The originality of this work is that, although the aim was to improve the catalytic performance with the addition of alumina, it is extremely interesting to obtain a high catalytic activity without alumina. This results in time and economic saving in the development of new technologies.

\section{ACKNOWLEDGEMENTS}

The authors gratefully acknowledge Universidad Nacional de San Luis, CONICET and ANPCyT

\section{REFERENCES}

1- K. Everaert, J. Baeyens, Hazard. Mater. 109, 113, (2004)

2- K. Everaert, M. Mathieu, J. Baeyens, E.V. Vansant, J. Chem. Technol. Biotechnol. 78, 167, (2003)

3- M. Alifanti, M. Florea, S. Somacescu, V.I. Parvulescu, Appl. Catal. B: Environ. 60, 33, (2005)

4- H.L. Tidahy, S. Siffert, F. Wyrwalski, J.F. Lamonier, A. Aboukais, Catal. Today 119, 317, (2007)

5- R. Dula, R. Janik, T. Machej, J. Stoch, R. Grabowski, E.M. Serwicka, Catal. Today 119, 327, (2007)

6- M.F. Ribeiro, J.M. Silva, S. Brimaud, A.P. Antunes, E.R. Silva, A. Fernandez, P. Magnoux, D.M. Murphy, Appl. Catal. B: Environ. 70, 384, (2007)

7- J.J. Spivey, Ind. Eng. Chem. Res. 26, 2165, (1987)

8- D.R. Van der Vaart, M.W. Vatavuk, A.H. Wehe, J. Air Waste Manage. Assoc. 41, 92, (1991)

9- D.R. Van der Vaart, M.W. Vatavuk, A.H. Wehe, J. Air Waste Manage. Assoc. 41, 497 (1991)

10- T. Garcia, B. Solsona, D.M. Murphy, K.L. Antcliff, S.H. Taylor, J. Catal. 229, $1,(2005)$

11- E.M. Cordi, J.L. Falconer, J. Catal., 162, 104, (1996)

12- J.C.S. Wu, Z.A. Lin, F.M. Tsai, J.W. Pan, Catal. Today. 63, 419, (2000)

13- J. Tsou, P. Magnoux, M. Guisnet, J.J.M. Orfao, J.L. Figueiredo, Appl. Catal. B: Environ. 57, 117, (2005)

14- E.M. Cordi, P.J. O’Neill, J.L. Falconer, Appl. Catal. B: Environ. 14, 23 (1997)

15- S.C. Kim, J. Hazard. Mater. B. 91, 285, (2002)

16- C.H. Wang, S.S. Lin, C.L. Chen, H.S. Weng, Chemosphere. 64, 503, (2006)

17- Eliminación de emisiones atmosféricas de COV's por catálisis y adsorción. Monografía multiautoral. Programa CYTED, Editores: T. Garetto, I. Legorburu, M. Montes, 2008, pág. 37-49.

18- L. Wang, T.P. Tran, D.V. Vo, M. Sakurai, H. Kameyama, Appl. Catal. A.
350, 150, (2008)

19- A. Paúl, J.A. Odriozola, M.A. San Miguel, J. Fernández Sanz, L.J. Álvarez, Acta mater. 48, 2951, (2000)

20- F.G. Durán, B.P. Barbero, L.E. Cadús, C. Rojas, M.A. Centeno, J.A. Odriozola, Appl. Catal. B 92, 194, (2009)

21- R. Lin, W. Liu, Y. Zhong, M. Luo, Appl. Catal. A. 220, 165 (2001)

22- C. Lahousse, C. Cellier, B. Belmon, P. Grange, Stud. in Surf. Sci. and Catal. 130, 587, (2000)

23- D. Frías, S. Nousir, I. Barrio, M. Montes, T. López, M.A. Centeno, J.A. Odriozola; Mater. Charac. 58, 776, (2007)

24- Y.N. Lee, R.M. Lago, J.L.G. Fierro, V. Cortés, F. Sapiña, E. Martínez, Appl. Catal. A. 207, 17, (2001)

25- M.R. Morales, B.P. Barbero, L.E. Cadús, Appl. Catal. B. 67, 229, (2006)

26- M.R. Morales, B.P. Barbero, L.E. Cadús, Appl. Catal. B. 74, 1, (2007)

27- F.G. Durán, L.E Cadús, B.P. Barbero, Latin American Applied Research. 42, 217, (2012)

28- P. Avila, M. Montes, E.E. Miró, Chem. Eng. J. 109, 11, (2005)

29- D.M. Frías, S. Nousir, I. Barrio, M. Montes, L.M. Martínez T, M.A. Centeno, J. A. Odriozola, Appl. Catal. A. 325, 205, (2007)

30- J. Jia, J. Zhou, J. Zhang, Z. Yuan, S. Wang, Appl. Surf. Sci. 253, 9099, (2007)

31- F. Romero-Sarria, A. Penkova, L.M. Martinez T. M.A. Centeno, K. Hadjiivanov, J.A. Odriozola, Appl. Catal. B. 84, 119, (2008)

32- L.M. Martínez T, O. Sanz, M.I. Domínguez, M.A. Centeno, J.A. Odriozola, Chem. Eng. J. 148, 191, (2009)

33- F. Durán, B.P. Barbero, Luis E. Cadús, Catal. Letter. 141, 1786, (2001)

34- J.P. Reymond, Catal. Today. 69, 343, (2001)

35- S. Yasaki, Y. Yoshono, K. Ihara, K. Ohkubo, US Patent 5208206, 1993

36- T. Lin, H.D. Xu, W. Li, Q.L. Zhang, M.C. Gong, Y.Q. Chen, Chem. J. Chin. Univ. 30(11), 2240, (2009)

37- P.R. Ettireddy, N. Ettireddy, S. Mamedov, P. Boolchand, P.G. Smirniotis, Appl. Catal. B. 76, 12, (2007)

38- W.S. Kijlstra, D.S. Brands, E.K. Poels, A. Bliek, J. Catal. 171, 208, (1997)

39- T. Lin, Q.L. Zhang, W. Li, Acta Phys-Chim Sin, 24, 1127, (2008)

40- K. Shen, Y. Zhang, X. Wang, H. Xu, K. Sun, C. Zhou, J. of Energy Chem. 22, 617, (2013)

41- Z.D. Zhu, M. Hartmann, E.M. Maes, R.S. Czernuszewicz, L. Kevan, J. Phys. Chem. B, 104, 4690, (2000)

42- M.M. Barroso Quiroga, B.P. Barbero, L.E. Cadús, Appl. Catal. A. 474, 26, (2014) 